\title{
Operationalizing Theories and Methods to Integrate Social Justice in LIS Scholarship
}

\author{
Guest Editor: \\ Bharat Mehra, University of Alabama, USA
}

Keywords: LIS scholarship; methods; research; scholarship; social justice; theories

Publication type: editorial

\section{Editorial}

n April 2021, with the indictment of the murderers of George Floyd and Ahmaud Arbery in the United States, the quest for racial justice found a sliver of hope. This sliver of hope gleamed only slightly though, for the genetic legacy of human oppressions and all forms of subjugation towards each other are deeply entrenched in our evolutionary record and cultural history. So too, are the interlocking social, cultural, political, and economic systems of privilege that systemically continue to favor some groups of people, while disenfranchising others from similar freedoms of thought, expression, equitable opportunity, and human fulfillment.

Thus, these momentous judicial verdicts serve as only a measure of justice. Yet, they provide an urgent opportunity for all of us to find the voice to speak up, speak out, and take actions to dismantle white privilege and to destabilize white superiority that all too often seem to throttle the whole of humanity into "the sunken place," an abyss of darkness. We, as library and information professionals across the world, still have much work to do to continue challenging the intersecting injustices we encounter in our everyday lives at work and at home, in all its ugly shapes and intensities. The journey to reform our institutions and communities and achieve any substantive transformations and measurable progressive changes is still a long, dark, and winding road.

In response to our contemporary racial trauma and political turbulence, this special issue of The International Journal of Information, Diversity, \& Inclusion (IJIDI) (Volume 5, Issue 2) highlights excellent examples of social justice scholarship in library and information studies (LIS) that illustrate intersecting theories and methods in the delivery of research, teaching, service, and engagement activities. This collection of articles includes novel contributions that exemplify creative weaving of these intersections that are empirical, methodological, theory-focused, pedagogical, and/or practical in nature. The purpose of this special issue is to bring together voices of both emerging and established LIS researchers with ranging interdisciplinary perspectives and transdisciplinary paradigmatic roots that embrace social justice as an intentional and deliberate strategy to generate impact via information-related work (Bernier, 2019; Cooke et al., 2016).

The term "scholarship" in the title of this special issue is intentionally used to serve multiple agendas. First, it contextualizes documentation and analysis through intersecting lenses of diverse theories and alternate methodologies from interdisciplinary and transdisciplinary origins

The International Journal of Information, Diversity, \& Inclusion, 5(2), 2021

ISSN 2574-3430, https://jps.library.utoronto.ca/index.php/ijidi

DOI: $10.33137 /$ ijidi.v5i2.36678 
to promote a social justice standard in LIS research and practice, education and teaching, policy development, service design, and program implementation. Furthermore, when we think of the term, "information scholarship" (embedded within the concept of "LIS scholarship") the idea also broadly reflects intersections and overlaps within the traditional teaching-researchservice/community engagement paradigm where these tenets are all too often treated as isolated and separate in an elitist and exclusionary Western-centric academy, with marginal relationships and relevance to community-embedded contexts (Mehra, in press; Mehra \& Gray, 2020). Also, the idea of "information scholarship" challenges privileged notions surrounding constricted and fragmented constructs of pedantic theory in information research that have been traditionally considered highbrow and separate from library practice or methodology. Further, the expression highlights the problems in the reliance on narrowly operationalized qualitative research in LIS during its infancy on primarily mimicking biased Western-centric sources of the social sciences (such as sociology, anthropology, and psychology) with their own shortcomings (e.g., internalization of positivist and postpositivist strategies and research representations exclusively disseminated through closed networks) (Creswell \& Creswell, 2018; Cronin, 2008; Fidel, 2008; Mehra, 2021a; Olson, 1995; Sandstrom \& Sandstrom, 1995). These unhealthy legacies might still be considered inherent, for example, in editorial practices of mainstream journals in LIS and beyond, that impose stringent word-count stipulations emerging from descriptions of positivist or postpositivist research on humanistic, interpretive, and critical scholarship, as if they are the same (Mehra, 2021b). This probably led to a "watering down" of their analysis in the latter, that then seemingly gets misperceived as incomplete, ad hoc, and lacking rigor. With a shift in perception for LIS scholarship in mind, this collection showcases research that adopt rigorous models, frameworks, theories, methods, and approaches to further social justice and inclusion advocacy in the LIS field to further principles of fairness, justice, and equality/equity for all people.

The six articles included in this collection selectively present a diverse array of LIS scholarship using intersecting theories and methods highlighted in their analysis. Table 1 summarizes this research collection in terms of their category/functional role, context of study, representative theoretical bent, operationalized research methods, and deliverable/implications for social justice scholarship in LIS.

Table 1. Overview of Issue Contents

\begin{tabular}{|c|c|c|c|c|c|}
\hline $\begin{array}{l}\text { Article Name and } \\
\text { Author }\end{array}$ & $\begin{array}{l}\text { Category/ } \\
\text { Functional } \\
\text { Role }\end{array}$ & Context of Study & Theoretical Bent & $\begin{array}{l}\text { Operationalized } \\
\text { Research Methods }\end{array}$ & $\begin{array}{l}\text { Implications for } \\
\text { Social Justice in LIS }\end{array}$ \\
\hline $\begin{array}{l}\text { More than Lip Service } \\
\text { (Winberry) }\end{array}$ & $\begin{array}{l}\text { Research/ } \\
\text { framing }\end{array}$ & $\begin{array}{l}\text { LISTA and LISS } \\
\text { databases }\end{array}$ & $\begin{array}{l}\text { Drawing ties between } \\
\text { theory and methods } \\
\text { in LIS }\end{array}$ & $\begin{array}{l}\text { Content analysis of } \\
247 \text { records }\end{array}$ & $\begin{array}{l}\text { Typology of social } \\
\text { justice in LIS } \\
\text { literature }\end{array}$ \\
\hline $\begin{array}{l}\text { Understanding Social } \\
\text { Justice through } \\
\text { Practitioners' } \\
\text { Language (Mills, } \\
\text { Kociubuk, \& } \\
\text { Campana) }\end{array}$ & $\begin{array}{l}\text { Research/ } \\
\text { framing }\end{array}$ & Public librarians & $\begin{array}{l}\text { Bridging divides in } \\
\text { theoretical notions of } \\
\text { equity, engagement, } \\
\text { and empowerment } \\
\text { across to the } \\
\text { practitioners' world }\end{array}$ & $\begin{array}{l}\text { Grounded theory } \\
\text { analysis of } 20 \text { semi- } \\
\text { structured interviews } \\
\text { with public library } \\
\text { staff }\end{array}$ & $\begin{array}{l}\text { Demonstrate a } \\
\text { complex, } \\
\text { multifaceted } \\
\text { portrait of how } \\
\text { practitioners } \\
\text { describe equity, } \\
\text { engagement, and }\end{array}$ \\
\hline
\end{tabular}

The International Journal of Information, Diversity, \& Inclusion, 5(2), 2021

ISSN 2574-3430, jps.library.utoronto.ca/index.php/ijidi/index

DOI: $10.33137 /$ ijidi.v5i2.36678 


\section{empowerment}

$\begin{array}{ll}\text { Case Study Inquiry \& } & \text { Research/ } \\ \text { Black Feminist } & \text { approaches + } \\ \text { Resistance (Gray) } & \text { context }\end{array}$

Meaning and Memory: Reconsidering the Appalachian Oral History Project (Sikes)

\section{Reflections of} research into the role of activistmothers in a Chicago public housing community

Research / approaches + context
Appalachian Oral History Project; Black identity in Central Appalachia
Role of familial in an ethnic, racial, and gendered community; Black feminist resistance

Community archival studies; oral histories and Black identity
Case study inquiry of the personal narrative; storytelling

Ethnographic methods in archival and historical scholarship

\section{Theorizing of educating archivists}

the field/ approaches + context

\section{Master of Archival Studies Program}

Viewpoints/
emerging domains

\author{
OCD as a form of \\ neurodivergence
}

Inclusivity of neurodiversity conferences
A Qualitative Study

Exploring

Neurodiversity

Conference Themes, Representations, and Issues of Inclusivity (Mellifont)

Significance of a critical-qualitative case study approach in community-focused research

\section{Complex} understanding of place and identity; reclaiming of stories and oral histories; space for traditional research to push boundaries and embrace political advocacy as an aspect of the fight for social justice Analysis of class
discussion activities +
course assignments

Content analysis of 22 conference flyers and 14 scholarly articles
Insights for development of social justice intersections in the archival education curriculum

Evidence-based justification for intersectionality and explicit inclusion of OCDfocused content in neurodivergence conferences

Note: Category/functional role, context of study, representative theoretical bent, operationalized LIS research methods, and deliverable/implications for social justice scholarship in LIS represented in the articles published in this special issue.

The first two research manuscripts play a "framing" representational role in the collection. Joseph Winberry's opening article "More than Lip Service: Identifying A Typology of "Social Justice" Research in LIS" presents a purely scholarly context in reporting findings of a literature review of self-identified "social justice" research in two large academic databases of LIS-The Library Information Science \& Technology Abstracts (LISTA) and Library and Information Science Source (LISS)-to identify the components that make social justice research intersections possible. The results present a valuable typology of two research types and eight sub-types for organizing existing social justice research within LIS, arguably as an emerging sub-discipline. J. Elizabeth Mills, Jacqueline Kociubuk, and Kathleen Campana's article "Understanding Social Justice Through Practitioners' Language” develops a critical semantic foundation of social justice 
concepts, situated within the public librarian practitioner's understanding. This works-inprogress study presents a grounded theory analysis of 20 semi-structured interviews with library staff and their community partners. The research explores and unpacks the practitioners' language to demonstrate a complex, multifaceted portrait of how these practitioners describe equity, engagement, and empowerment.

The next two research manuscripts describe select approaches and contextual settings for the study of social justice in LIS. LaVerne Gray's article "Case Study Inquiry \& Black Feminist Resistance: Reflections on a Methodological Journey in the Furtherance of LIS Social Justice Research" explains the researcher's ownership of tools of inquiry using personal narrative. Using the researcher's journey as an example, a narrative inquiry approach is explored through a theoretical and methodological iterative case development process. The paper calls for a need in LIS social justice inquiry models to utilize a critical-qualitative approach of case study development in the pursuit of community-focused research. Scott Sikes' contribution, "Meaning and Memory: Reconsidering the Appalachian Oral History Project," employs emerging ethnographic methods in archival work and historical scholarship to provide an enhanced understanding of place and identity, allowing for a reclaiming of stories by Black residents in Central Appalachia, United States. In this process, the author generates intellectual space within the intersections of theory, method, and discipline of traditional information science research to advance the discipline's boundaries by embracing political advocacy as an aspect of the fight for social justice.

Joshua F. Kitchens' article “Engaging with Silences: Clayton State Master of Archival Studies Program's Approach to Teaching" reports from the field and discusses the theoretical underpinnings to educating archivists, systematically integrating social justice in its various components. Analysis of class discussion activities and assignments illustrate how an archival education curriculum can prepare students to engage with issues of representation in archival collections once they are in the field. The last article by Damian Mellifont entitled "A Qualitative Study Exploring Neurodiversity Conference Themes, Representations, and Issues of Inclusivity" represents a special viewpoint in emerging opportunities as it critically investigates inclusion in conferences related to OCD-focused content. The exploratory research applies content analysis of 22 conference flyers and 14 scholarly articles to generate evidence-based justifications for a greater inclusion and intersectionality in generating future conference themes and representations.

I was or currently am affiliated with three doctoral committees of authors in this collection. Their work as well as those of others went through a rigorous review process to sharpen, strengthen, and eventually polish the manuscripts to make them shine. I intentionally draw attention to these professional connections with the authors in order to take ownership of my positionality and situatedness of these social and professional ties in the emergence of this LIS scholarly network of social justice advocates. Through the process, I also challenge misrepresented notions of objectivity of positivist and postpositivist researchers and their reliance on citing each other's work in high impact-factor journals that failed to acknowledge the existence of their "invisible colleges" for a very long time (Crane, 1972). Here, my strategy to "make visible" my own professional ties with the authors is a direct confrontation of these lapses of the past. Further, my critical strategy serves to pinpoint the "dirty economics" associated with the scholarly publication business models that have created partial tenure and promotion policies favoring positivist and postpositivist research in their predominant resistance to action research, social justice/advocacy, and community-engaged scholarship, amongst other

The International Journal of Information, Diversity, \& Inclusion, 5(2), 2021

ISSN 2574-3430, jps.library.utoronto.ca/index.php/ijidi/index

DOI: $10.33137 /$ ijidi.v5i2.36678 
alternate modes of assessment and research productivity (Mehra, Bishop, \& Partee II, 2018). The development of such a social network of LIS professionals as social justice advocates involved in social justice scholarship is noteworthy. The emergence of social justice-oriented LIS research is significant within LIS and its predominant majorities of white and female constituents that have sustained their own hegemonic canons, theories, methods, and paradigms to entrench themselves and their impact, while including some and excluding others.

I truly appreciate the partnership with $I J I D I$ in providing a valuable opportunity to publish emerging scholarship in this regard. Developing such a collection allowed for exploring creative integrations of LIS theories and methods to further social justice agendas through a scholarly venue. The generosity and commitment of the editorial staff and anonymous reviewers in providing timely, constructive, and detailed feedback on the manuscripts was most humbling.

The epistemic protest waves against racially motivated police hostilities (e.g., Black Lives Matter movement) have exposed the wide and deep cracks in the practice of American justice, equality, freedom, human dignity, fair government, and the "Life, Liberty, and the pursuit of Happiness" espoused in United States Declaration of Independence (U. S. Citizenship and Immigration Services, 2007/2008). LIS professionals have played a limited role in applying their theory development and methods applications (amongst other efforts) to mobilize actions in supporting the recent public outcry for an immediate stop to human rights violations of African Americans and other racial minorities in the United States (Carney, 2016; Lebron, 2017; Mehra, 2021c). LIS professionals now have this potential to extend their scholarship from its shackles of a limited past and current constraints (Winberry \& Bishop, 2021). The contextual situatedness in this current problematic racial age and political divisiveness in its scale of horror, which includes: implications of racial violence, propensity of white resistance to justice, degree of intensity in the public outrage, and its national-and-global spread has now forced complacent LIS scholars and educators (amongst others) around the world to integrate action-oriented social justice efforts of community activism, racial advocacy, and progressive change (Mehra, 2021b; Cooke 2020).

Social justice and inclusion advocacy in LIS through an information lens of analysis and communication action can promote fairness, justice, and equality/equity for all people. In the past LIS scholars have tip-toed around these issues, clinging on to outdated notions of perceived neutrality, being passive bystanders as community dynamics enfold, and exhibiting resistance to decenter their inherent privileged positions of power and authority (Gibson et al., 2017). The selected articles in this special issue begin to challenge some of these blinders and provide a glimpse of how progressive LIS scholars are drawing on varied intersections of theory and methods to generate social justice impacts that are intentional (deliberate), systematic (rigorous), action oriented, and outcome-driven to deliver meaningful information systems, services, and other forms of information products (Jaeger et al., 2014; Mehra et al., 2019). They illustrate ways to address the gap of the "how-tos" in developing LIS scholarship and technological deliverables that change imbalanced status quo power dynamics in tangible and meaningful ways (Allen et al., 2019).

In conclusion, I share select themes and my strategies in compiling this collection. I tried to focus on action-oriented initiatives in LIS scholarship that further social justice principles in specific contextual settings of lapse. The degree and intensity of actions and the involvement of various internal and external stakeholders obviously varied. We will continue to see a threading of emerging LIS and non-LIS theoretical and conceptual groundings in conjunction with traditional

The International Journal of Information, Diversity, \& Inclusion, 5(2), 2021

ISSN 2574-3430, jps.library.utoronto.ca/index.php/ijidi/index

DOI: $10.33137 /$ ijidi.v5i2.36678 
and non-traditional methods and methodologies to further aspects of impact beyond the ivory tower of the academy.

LIS scholars are beginning to apply entrenched research paradigms and methods of the past (e.g., postpositivist and quantitative approaches) towards new conceptualized research modes in their study of social justice content and related matters of significance. These efforts represent a new wave of social justice scholarship and provide possible beginnings for postpositivist researchers to engage more deeply in the explorations of relevance of their work towards social justice concerns. The "so what" implications and specific strategies to change the existing scenarios of inequities and conditions of marginalization will continue getting strengthened with such efforts. For example, it is more than an occurrence of "social justice" vocabularies in various exclusive electronic databases to identify trends in a White-IST (white + elitist) LIS scholarship that makes the research itself, an example of social justice work (Mehra \& Gray, 2020). Also, documenting the number and themes from big datasets of online contributions of diverse underserved constituencies on Twitter about their experiences and perspectives, presents a correlation distribution or regression analysis of the findings. What is done as a result of these research findings and what role underserved stakeholders are playing in making changes to their disenfranchised circumstances are valuable directions in social justice to explore such examples. Tangible and concrete information-related deliverables that improve an understanding of a phenomenon under study AND provide actions to change deliberating conditions, are valuable goals to consider in forthcoming LIS scholarship integrating social justice theories and methods. That said, this collection of social justice LIS research contributes to the ongoing discourse within our profession that can lead towards individual and social empowerment, change agency, community building, and community development outcomes, thereby, generating greater impact beyond our predominantly White-IST isolated ivory towers of the academy and other exclusive spaces of power and privilege (Mehra \& Gray, 2020).

\section{References}

Allen, D., Given, L. M., Burnett, G., \& Karanasios, S. (2019). Guest editorial: Information behavior and information practices: A special issue for research on people's engagement with technology. Journal of the Association for Information Science \& Technology 70(12), 1299-1301. https://doi.org/10.1002/asi.24303

Bernier, A. (2019). Isn't it time for youth services instruction to grow up? From superstition to scholarship. Journal of Education for Library and Information Science 60(2), 118-138. https://doi.org/10.3138/jelis.2018-0055

Carney, N. (2016). All lives matter, but so does race: Black Lives Matter and the evolving role of social media. Humanity \& Society 40(2), 180-199.

https://doi.org/10.1177\%2F0160597616643868

Cooke, N. A. (2020, September 11). Turning antiracist knowledge and education into action. Publishers Weekly. https://www.publishersweekly.com/pw/by-topic/industrynews/libraries/article/84313-are-you-ready-to-stand-in-the-gap.html

Cooke, N. A., Sweeney, M. E. \& Noble, S. U. (2016). Social justice as topic and tool: An

The International Journal of Information, Diversity, \& Inclusion, 5(2), 2021

ISSN 2574-3430, jps.library.utoronto.ca/index.php/ijidi/index

DOI: $10.33137 /$ ijidi.v5i2.36678 
attempt to transform a LIS culture and curriculum. The Library Quarterly: Information, Community, Policy 86(1), 107-124. https://doi.org/10.1086/684147

Crane, D. (1972). Invisible colleges. University of Chicago Press.

Creswell, J. W., \& Creswell, J. D. (2018). Research design: Qualitative, quantitative, and mixed methods approaches ( $5^{\text {th }}$ edition). Sage.

Cronin, B. (2008). The sociological turn in information science. Journal of Information Science 34(4), 465-475. https://doi.org/10.1177\%2F0165551508088944

Fidel, R. (2008). Are we there yet?: Mixed methods research in library and information science. Library \& Information Science Research 30(4), 265-272.

https://doi.org/10.1016/j.lisr.2008.04.001

Gibson, A. N., Chancellor, R. L., Cooke, N. A., Dahlen, S. P., Lee, S. A., \& Shorish, Y. (2017). Libraries on the frontlines: Neutrality and social justice. Libraries 99. http://commons.lib.jmu.edu/letfspubs/99

Jaeger, J. T., Gorham, U., Taylor, N. G., \& Kettnich, K. (2014). Library research and what libraries actually do now: Education, inclusion, social services, public spaces, digital literacy, social justice, human rights, and other community needs. The Library Quarterly: Information, Community, Policy 84(4), 491-493. https: / / doi.org/10.1086/677785

Lebron, C. J. (2017). The making of Black Lives Matter: A brief history of an idea. Oxford University Press.

Mehra, B. (in press). Social justice design and implementation: Innovative pedagogies to transform LIS education. Journal of Education for Library and Information Science 62(4).

Mehra, B. (2021a). Elfreda Annmary Chatman in the $21^{\text {st }}$ century: At the intersection of critical theory and social justice imperatives. Journal of Critical Library and Information Studies 3 (Special Issue Chatman Revisited: Re-examining and Resituating Social Theories of Identity, Access, and Marginalization in LIS. Edited by N. A. Cooke and A. N. Gibson). https://journals.litwinbooks.com/index.php/jclis/article/view/142

Mehra, B. (2021b). Overcoming interrelated challenges to "Diversity by Design" in the LIS tenure and promotion process in the American academy. In K. Dali and N. Caidi (Eds.), Humanizing LIS education and practice: Diversity by design (pp. 105-118). Routledge.

Mehra, B. (2021c). Enough crocodile tears! Libraries moving beyond performative antiracist politics. The Library Quarterly: Information, Community, Policy 91(2), 137-149. https://doi.org/10.1086/713046

Mehra, B., Bishop, B. W., \& Partee II, R. P. (2018). A case methodology of action research to promote economic development: Implications for LIS education. Journal of Education for Library and Information Science 59(1-2), 48-65. https://doi.org/10.3138/jelis.59.1$\underline{2.06}$ 
Mehra, B., Elmborg, J., \& Sweeney, M. (2019). A curricular model in a "Social Justice and Inclusion Advocacy" doctoral concentration: Global implications for LIS (Juried Paper). Proceedings of the Association for Library and Information Science Education (ALISE) Annual Conference: Exploring Learning in a Global Information Context, Knoxville, Tennessee, September 24-26, 2019.

Mehra, B., \& Gray, L. (2020). An "owning up” of White-IST trends in LIS to further real transformations. The Library Quarterly: Information, Community, Policy 90(2), 189239. https://doi.org/10.1086/707674

Olson, H. (1995). Quantitative "versus" qualitative research: The wrong question. Proceedings of the Annual Conference of the Canadian Association for Information Science. https://journals.library.ualberta.ca/ojs.cais-acsi.ca/index.php/caisasci/article/view/414/362

Sandstrom, A. R., \& Sandstrom, P. E. (1995). The use and misuse of anthropological methods in library and information science research. The Library Quarterly: Information, Community, Policy 65(2), 161-199. https://doi.org/10.1086/602775

U. S. Citizenship and Immigration Services. (2007/2008). (revised). The Declaration of Independence and the Constitution of the United States. U. S. Citizenship and Immigration Services.

https://www.uscis.gov/sites/default/files/USCIS/Office\%200f\%20Citizenship/Citizenshi p\%20Resource\%20Center\%20Site/Publications/PDFs/M-654.pdf

Winberry, J. \& Bishop, B.W. (2021). Documenting social justice in library and information science research: A literature review. Journal of Documentation 77(3). https://doi.org/10.1108/JD-08-2020-0136

Bharat Mehra (bmehra@ua.edu) joined the School of Library and Information Studies at the University of Alabama as Professor and EBSCO Endowed Chair in Social Justice in January 2019. From January 2005 to December 2018, he was a faculty member in the School of Information Sciences at the University of Tennessee. His research focuses on diversity and social justice in library and information science and community informatics or the use of information and communication technologies to empower minority and underserved populations to make meaningful changes in their everyday lives. He has applied action research to further engaged scholarship and community engagement while collaborating with racial/ethnic groups, international diaspora, LGBTQ+ people, rural communities, low-income families, small businesses, and others, to represent their experiences and perspectives in the design of community-based information systems and services. Homepage: bmehra.people.ua.edu. 